\title{
Comment on "Estimating the depth and evolution of intrusions at resurgent calderas: Los Humeros (Mexico)" by Urbani et al. (2020)
}

\author{
Gianluca Norini and Gianluca Groppelli \\ Istituto di Geologia Ambientale e Geoingegneria, Sezione di Milano, Consiglio Nazionale delle Ricerche, Milan, Italy
}

Correspondence: Gianluca Norini (gianluca.norini@cnr.it)

Received: 1 October 2020 - Discussion started: 6 October 2020

Revised: 17 November 2020 - Accepted: 20 November 2020 - Published: 23 December 2020

\begin{abstract}
A multiple shallow-seated magmatic intrusion model has been proposed by Urbani et al. (2020) for the resurgence of the Los Potreros caldera floor, in the Los Humeros volcanic complex (LHVC). This model predicts (1) the occurrence of localized bulges in the otherwise undeformed caldera floor, and (2) that the faults corresponding to different bulges exhibit different spatial and temporal evolution. Published data and a morphological analysis show that these two conditions are not met at Los Potreros caldera. A geothermal well (H4), located at the youngest supposed bulge (Loma Blanca) for which Urbani et al. (2020) calculated an intrusion depth $(425 \pm 170 \mathrm{~m})$, does not show any thermal and lithological evidence of such a shallowseated cryptodome. Finally, published stratigraphic data and radiometric dating disprove the proposed common genesis of Holocene resurgence faulting and viscous lavas extruded in the centre of the caldera. Even if recent shallow intrusions do exist in the area, published data indicate that the pressurization of the LHVC magmatic-hydrothermal system driving resurgence faulting occurs at greater depth. Thus, we suggest that the model and calculation proposed by Urbani et al. (2020) are unlikely to have any relevance to the location, age and emplacement depth of magma intrusions driving resurgence at the Los Potreros caldera.
\end{abstract}

\section{Introduction}

Urbani et al. (2020) (henceforth U2020) made a contribution to the study of caldera resurgence based on field data and geothermal well logs from the Los Humeros volcanic complex (LHVC) and scaled analogue models. U2020 constrained the spatial-temporal evolution of post-caldera vol- canism at LHVC and estimated the depth of the magmatic intrusions feeding the active geothermal system by integrating fieldwork data, well logs and laboratory results. The main conclusion of U2020 is that the resurgence of the Los Potreros caldera in the LHVC "is due to multiple deformation sources", "linked to small magmatic intrusions located at relatively shallow depths (i.e. $<1 \mathrm{~km}$ ). U2020 suggested that these intrusions are located below three uplifted areas surrounding the Arroyo Grande, Los Humeros and Loma Blanca faults.

The analysis by U2020 suffers from poor field data and contradictions with thermal remote sensing data (Sect. 2), geometric and structural inconsistencies between the LHVC post-caldera deformation and the analogue modelling (Sect. 3), lack of any substantial validation of the results with published well logs (Sect. 4), and incongruities with the reference stratigraphy and radiometric ages recently published by some of the U2020 authors (Sect. 5). These problems, which largely undermine the U2020 conclusions, are discussed below.

\section{Location and relative age of faulting - field data and thermal remote sensing}

U2020 analysed the occurrence and relative age of faulting and proposed a new interpretation of some structures identified by previous works, by studying faults and hydrothermal alteration in the Holocene Cuicuiltic Member unit (Ferriz and Mahood, 1984; Arellano et al., 2003; Dávila-Harris and Carrasco-Núñez, 2014; Norini et al., 2015, 2019). The Cuicuiltic Member blankets the Los Potreros caldera floor (Fig. 1), is very well exposed, has been dated at ca. $7 \mathrm{ka}$ and is made of alternated fallout deposits of different compositions 


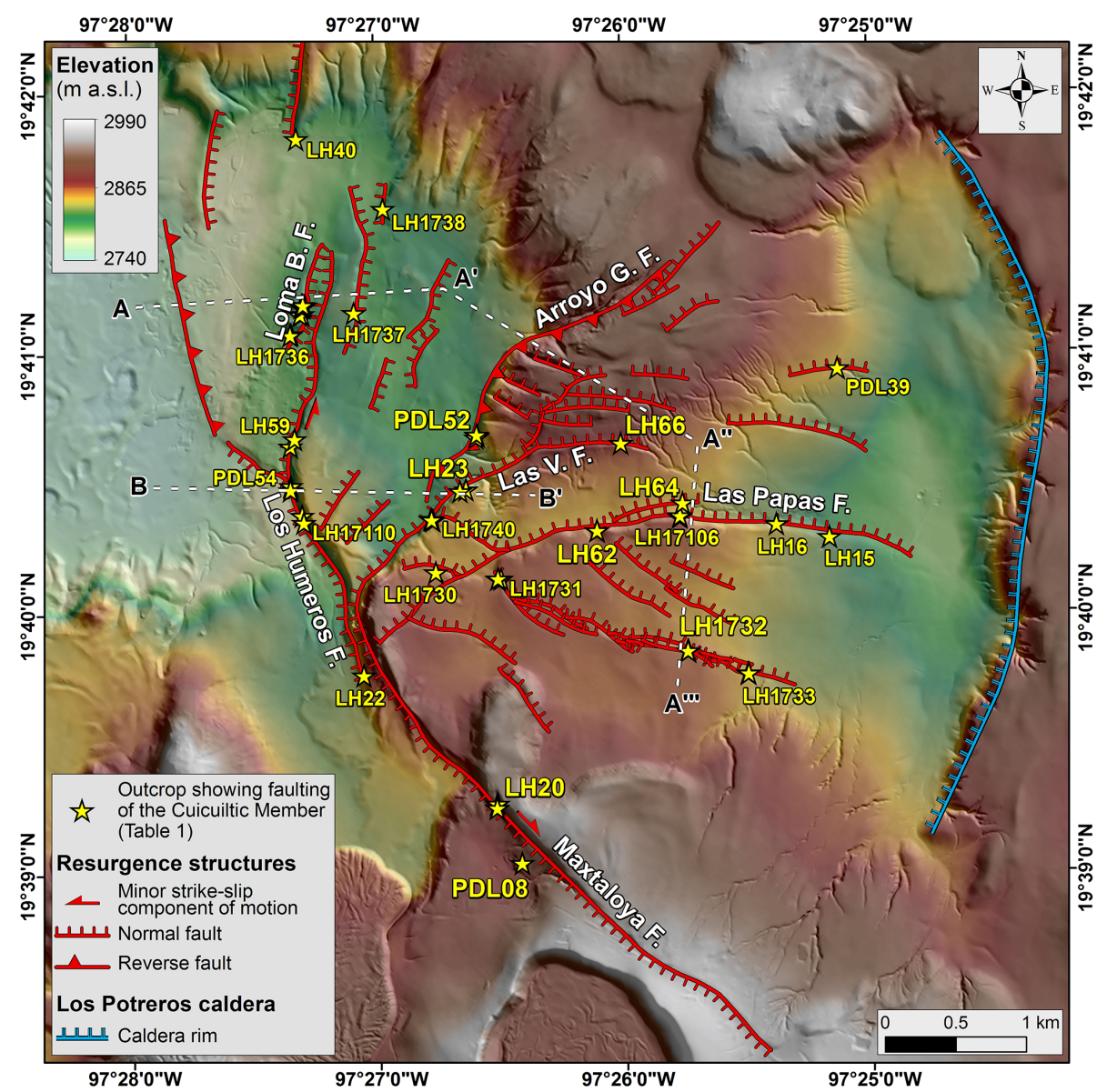

Figure 1. Volcanotectonic map of the Los Potreros caldera area, on a DEM (illuminated from the east) (modified from GEMex, 2019, and Norini et al., 2019). Las V. F.: Las Viboras fault; Arroyo G. F.: Arroyo Grande fault; Loma B. F.: Loma Blanca fault. Location of outcrops in Fig. 2 and Table 1 is shown. Traces of $A-\mathrm{A}^{\prime}-\mathrm{A}^{\prime \prime}-\mathrm{A}^{\prime \prime \prime}$ and $\mathrm{B}-\mathrm{B}^{\prime}$ topographic profiles of Fig. 4 are also shown.

(Dávila-Harris and Carrasco-Núñez, 2014). The Cuicuiltic Member has been considered an ideal marker layer for documenting Holocene faulting and stratigraphy in the caldera complex, because of the contrasting black and white colours of the fallout deposits composing the unit (e.g. Ferriz and Mahood, 1984; Dávila-Harris and Carrasco-Núñez, 2014; Norini et al., 2015, 2019; GEMex, 2019; U2020) (Figs. 1 and 2). The reinterpretation by U2020 has been based on their field data (22 fault data in three outcrops), distinguishing between lineaments ("morphological linear scarps with no measurable fault offsets and/or alteration at the outcrop scale) and active and inactive faults ("associated with measurable fault offsets and with active or fossil alteration"). The reinterpreted structures are the Las Papas, Las Viboras, Arroyo Grande and Maxtaloya faults (Fig. 1).

We discuss the U2020 reinterpretation below, considering published field data (175 fault data in 24 outcrops; Figs. 1 and 2; Table 1) and thermal remote sensing data (Fig. 3) (Norini et al., 2015, 2019; GEMex, 2019).

\subsection{Las Papas and Las Viboras faults}

U2020 concluded that the Las Papas and Las Viboras are "morphological scarps" and "lineaments" not related to faulting. For the Las Papas lineament, U2020 stated that "unaltered and undeformed deposits of the Cuicuiltic Member crop out along the E-W Las Papas lineament" and that this "is probably due to differential erosion of the softer layers of the pyroclastic deposits". Even if the Las Papas and Las Viboras structures were several kilometres long, the statements by U2020 have only been based on one outcrop on the Las Papas trace (U2020 LH-08 outcrop, while the LH-07 outcrop is out of the fault trace; see Fig. 4c).

Several outcrops exist along the Las Papas and Las Viboras faults, as well as along many other faults in the area surrounding these two main volcanotectonic structures (Fig. 1) (e.g. Dávila-Harris and Carrasco-Núñez, 2014; Norini et al., 2015, 2019; GEMex, 2019). In all these outcrops, the faults invariably displace the Holocene Cuicuiltic Member and the underlying lava and pyroclastic units (Figs. 1 and 2; Table 1). These data (Table 1) are incompatible with the U2020 con- 

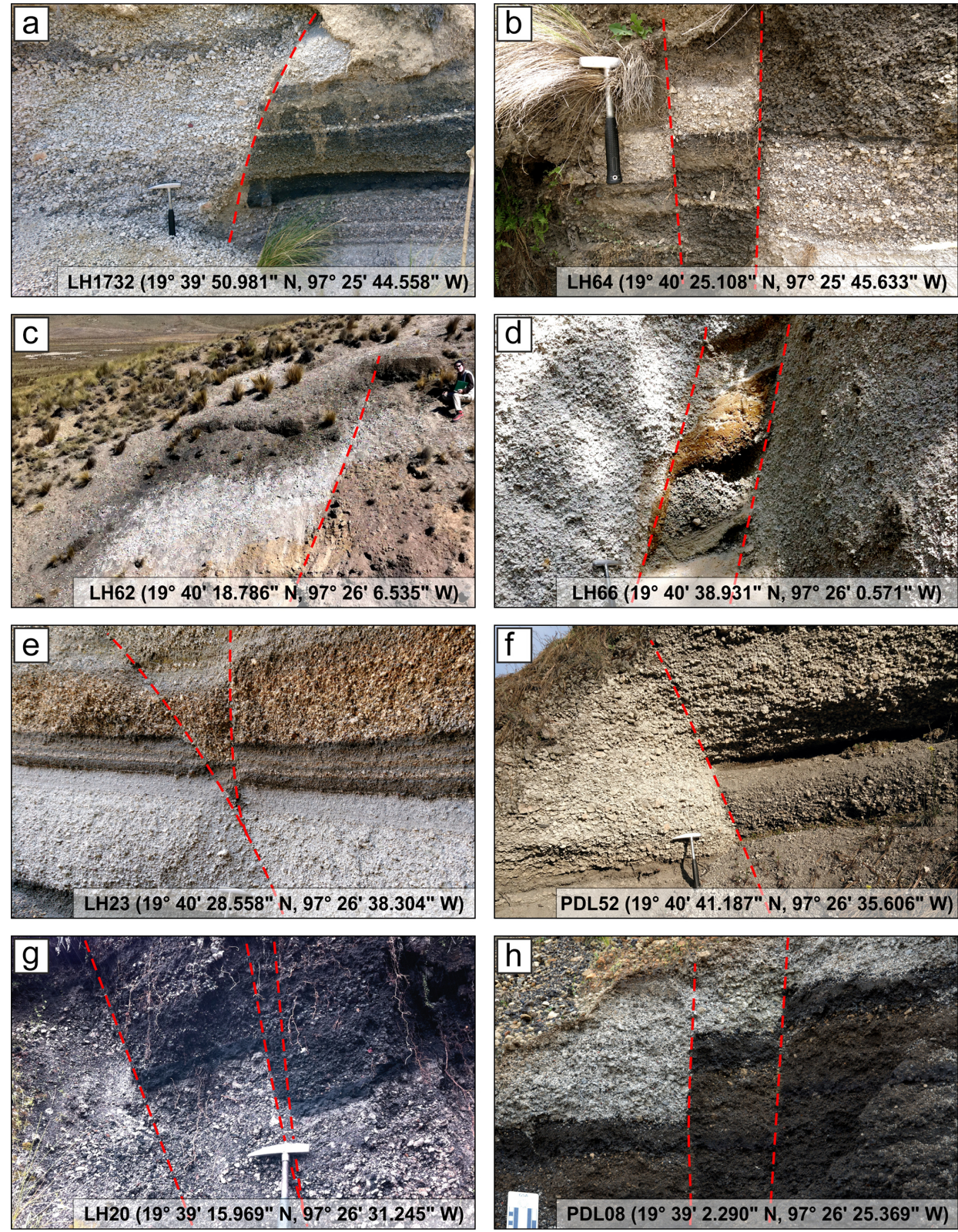

Figure 2. Photographs of faults in the Cuicuiltic Member along the structures mapped in Fig. 1.

clusion that the Las Papas and Las Viboras are not faults. Indeed, the data indicate that the Las Papas and Las Viboras structures originated in the Holocene by faulting (Figs. 1 and 2 and Table 1) (Dávila-Harris and Carrasco-Núñez, 2014; Norini et al., 2015, 2019; GEMex, 2019). The U2020 description of their LH-08 outcrop can be explained by erosive retreat of the fault scarp, a common process in dip-slip faults, especially in poorly consolidated sediments (e.g. Keller and Pinter, 2002; Burbank and Anderson, 2011).

\subsection{Arroyo Grande and Maxtaloya faults}

U2020 inferred that the Arroyo Grande and Maxtaloya scarps have been generated by nowadays-inactive faults. U2020 stated that these faults had been active "prior to the deposition of the Cuicuiltic Member". The statement by U2020 arose from the analysis of two outcrops (their LH-09, see Fig. 4c, and the H6 well pad, corresponding to the PDL08 outcrop of Figs. 1 and $2 \mathrm{~h}$ ), where "strongly altered and faulted ... lavas and ignimbrites" are "covered by the unaltered Cuicuiltic Member". Active or fossil alteration does not always allow for identifying faults or the age of faulting, because this also depends on their depth, life span of the 


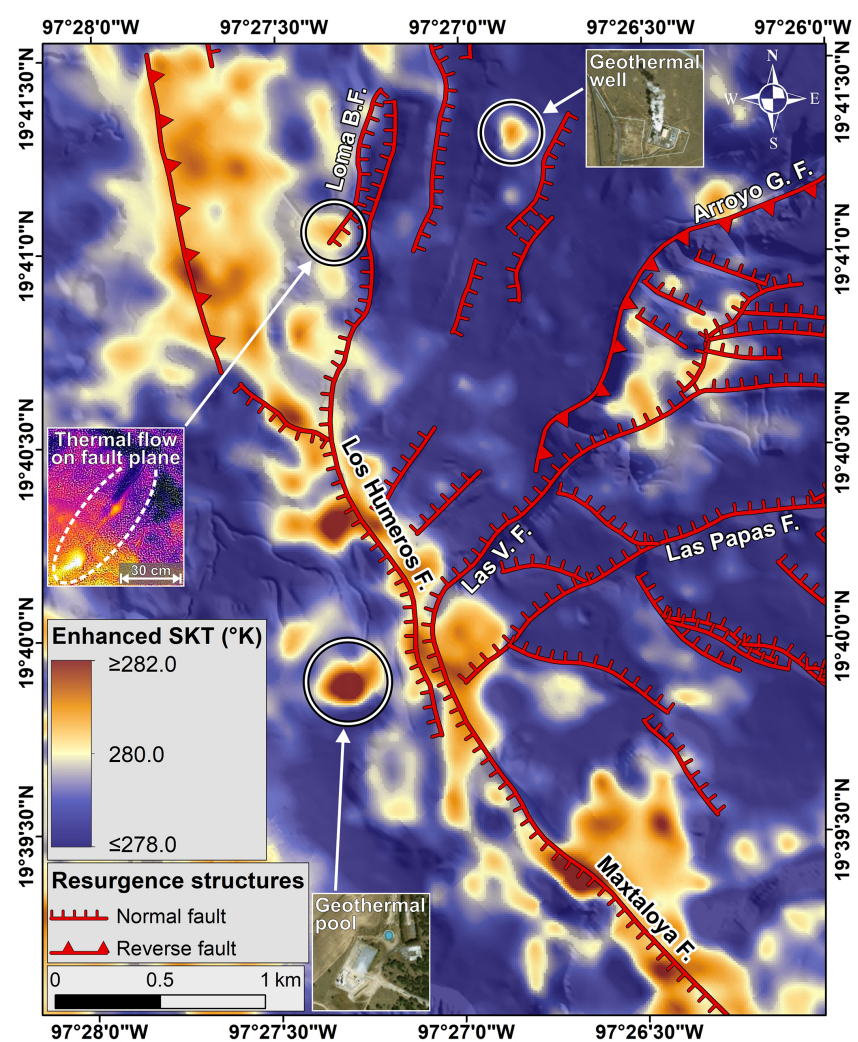

Figure 3. Enhanced surface kinetic temperature (SKT) of the Los Potreros caldera obtained from Advanced Spaceborne Thermal Emission and Reflection Radiometer (ASTER) AST_08 nighttime thermal remote sensing data (see Norini et al., 2015, for details on methods and results). Examples of field-validated sources of thermal anomalies are shown in the insets (Norini et al., 2015, 2019). Thermal satellite data: credits LP DAAC, USGS EROS data centre at NASA. Satellite images in the insets: credits Esri, DigitalGlobe, GeoEye.

hydrothermal system, spatial relationships, and fluid paths along primary permeability and fracture zones (e.g. Bonali et al., 2015; Giordano et al., 2016).

Outcrops of the Arroyo Grande and Maxtaloya faults show displacements of the Cuicuiltic Member, which are incompatible with the conclusion of U2020 about the age of these two structures and the correlation between faulting and hydrothermal alteration (Figs. 1 and 2; Table 1). The field data (Figs. 1 and 2 and Table 1) indicate that the Arroyo Grande and Maxtaloya faults were active after the deposition of the Cuicuiltic Member (Dávila-Harris and Carrasco-Núñez, 2014; Norini et al., 2015, 2019; GEMex, 2019).

The Maxtaloya fault trace is coincident with a sharp thermal anomaly identified by Norini et al. (2015) (Fig. 3). U2020 did not consider this positive (warm) anomaly when they discussed the thermal remote sensing results published by Norini et al. (2015) (Sect. 5.3 in U2020). The thermal remote sensing data (Fig. 3) suggest that the Maxtaloya fault nowadays plays an important role in the ascent of hot geothermal fluids (Norini et al., 2015, 2019; Carrasco-Núñez et al., 2017; GEMex, 2019).

The Maxtaloya positive thermal anomaly constitutes the southern branch of a narrow warm corridor (T1 of Norini et al., 2015), which is spatially coincident with the NNWSSE fault swarm represented by the Maxtaloya fault, Los Humeros fault, and some sub-parallel normal and reverse fault strands (Fig. 3) (Norini et al., 2019). This 7-8 km long thermal anomaly is incompatible with the presence of the "shallow and delocalized heat sources" proposed by U2020 (Fig. 3). Instead, the great length of this narrow thermal anomaly is consistent with a deeper pressure source driving resurgence faulting (e.g. an asymmetric cup-shaped intrusion), with lower surface temperatures in the centre of the thick resurgent block (cold area to the east of the $7-8 \mathrm{~km}$ long warm anomaly in Fig. 3) (see Norini et al., 2015).

\section{Identification and geometry of uplifted areas - topographic data and structural mapping}

U2020 identified three "main uplifted areas" surrounding the surface expressions of the Loma Blanca, Arroyo Grande and Los Humeros faults. U2020 did not provide any information on how these uplifted areas have been identified and delimited with specific and reproducible criteria. The area around the Loma Blanca fault has been named by U2020 "Loma Blanca bulge" and described as "a morphological bulge, $1 \mathrm{~km}$ in width and $30 \mathrm{~m}$ in height". The U2020 model also predicts the formation of an "apical depression" on top of a "bulge" induced by a shallow magmatic intrusion. Indeed, U2020 depicted apical depressions on top of the three "uplifted areas" of Loma Blanca, Arroyo Grande and Los Humeros (e.g. cross sections in Fig. 10 by U2020).

Topographic profiles of the Los Potreros caldera floor extracted from a $1 \mathrm{~m}$ resolution digital elevation model (DEM) (Norini et al., 2019) show that the "uplifted areas" (or "bulges") identified by U2020 include asymmetric reliefs and depressed sectors and have boundaries not necessarily corresponding to slope changes useful for their delimitation (Figs. 1 and $4 \mathrm{a}-\mathrm{c}$ ). The "Loma Blanca bulge" defined by U2020 comprises a sector of a larger and uniform westwardtilted and faulted surface (Norini et al., 2019). The western boundary of the "bulge" is in the middle of the tilted surface, while the eastern one, corresponding to a normal fault, is nearly at the same elevation of the summit of the "bulge" (Figs. 1 and 4a) (Carrasco-Núñez et al., 2017; Norini et al., 2019). Similarly, the eastern and western boundaries of the Arroyo Grande and Los Humeros "uplifted areas" have been located by U2020 in the middle of tilted or flat surfaces. The topographic data extracted from the $1 \mathrm{~m}$ resolution DEM (Figs. 1 and $4 \mathrm{a}-\mathrm{b}$ ) are incompatible with the occurrence of the "main uplifted areas" or "bulges" identified by U2020. The same topographic data are also incompatible with the occurrence of any "apical depression" along the Arroyo Grande 

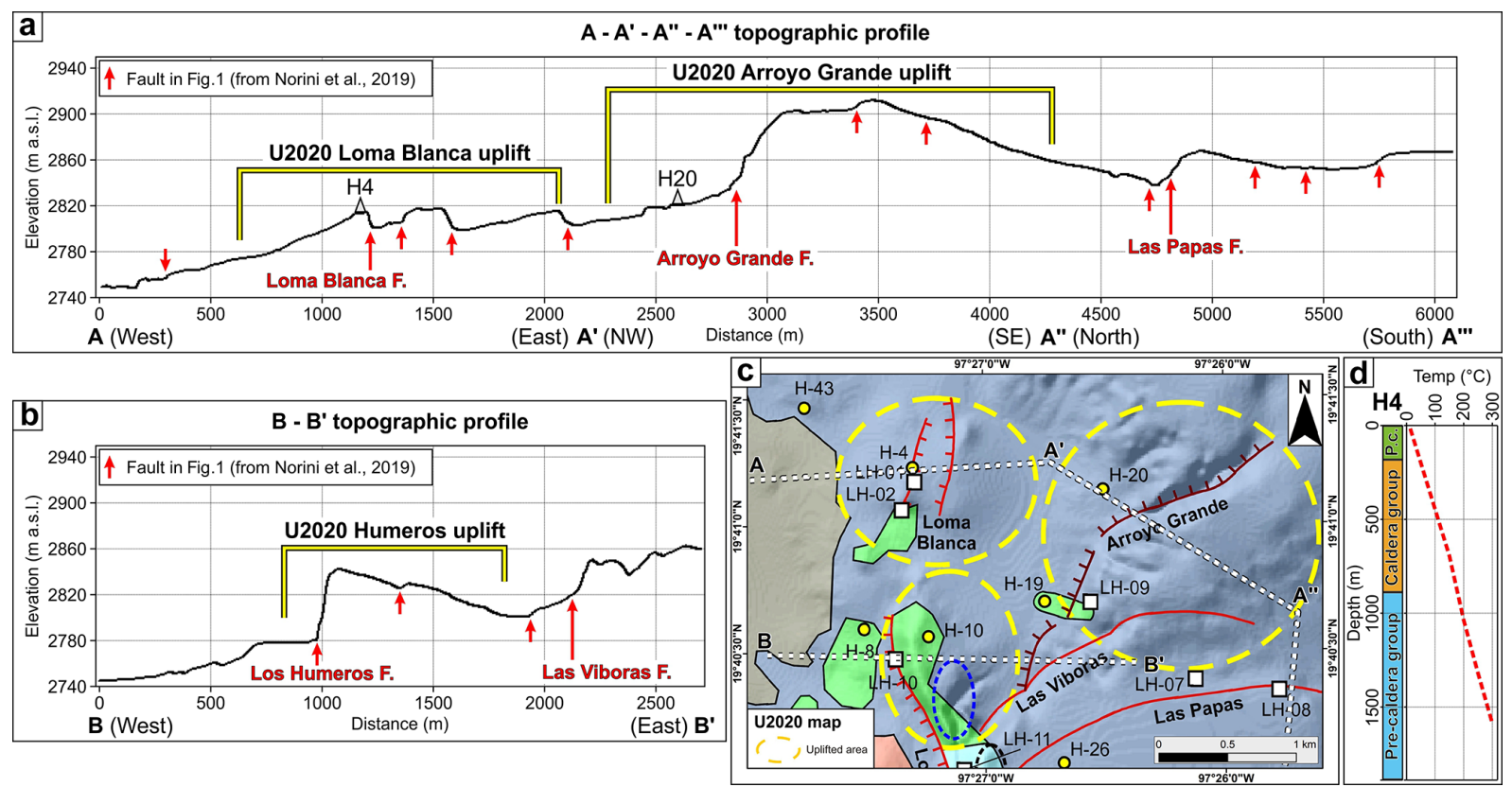

Figure 4. Topographic profiles along the (a) $\mathrm{A}-\mathrm{A}^{\prime}-\mathrm{A}^{\prime \prime}-\mathrm{A}^{\prime \prime \prime}$ and (b) $\mathrm{B}-\mathrm{B}^{\prime}$ traces shown in Fig. 1 and (c) schematic geological map (modified from U2020) outlining the three uplifted areas discussed by U2020; the traces of the two topographic profiles and the locations of the H4 and H20 wells are also shown. (d) H4 lithological and temperature log (well data from Arellano et al., 2003, and U2020). P.c.: post-caldera group.

and Los Humeros faults, suggesting that the present topography of the caldera floor does not have any relation with the "uplifted areas", "bulges" and "apical depressions" presented by U2020 (Figs. 1 and $4 a-c$ ).

The analogue modelling by U2020 predicts the development of reverse faults at the base of the "bulges" induced by the emplacement of shallow-seated cryptodomes (e.g. Fig. 7 by U2020). U2020 did not provide any field data or other evidence (morphostructural interpretation, geophysics, well logs, etc.) locating these reverse faults, which are a fundamental feature of their model. Reverse faults of this type have been identified in natural cases of shallow-seated intrusions (e.g. Sibbett, 1988; Jackson and Pollard, 1990; Schofield et al., 2010; Wilson et al., 2016).

Structural maps of the Los Potreros caldera published by Carrasco-Núñez et al. (2017), Calcagno et al. (2018), Norini et al. (2019) and U2020 are inconsistent with the idea of reverse faults at the base of the "bulges" identified by U2020 (Figs. 1 and 4c). The "Loma Blanca bulge" is delimited to the east by a normal fault mapped by Carrasco-Núñez et al. (2017) and Norini et al. (2019) (Fig. 4a).

\section{Validation of the proposed model - geothermal well log data}

One of the most significant findings of U2020 is that the uplift in the "Loma Blanca bulge" has been generated by a magmatic intrusion located at $425 \pm 170 \mathrm{~m}$ of depth. U2020 also stated that this is the heat source of the local geothermal anomaly. Such a shallow depth is within the range of geothermal wells drilled in the area. A validation attempt of the U2020 model in the "Loma Blanca bulge" consists in the comparison of the temperature and lithological H4 well log with the predicted intrusion depth. This well is located at the top of the "bulge", just to the west of its "apical depression" (Fig. 4a, c). The H4 well log should show a significant temperature change and intrusive or sub-volcanic lithologies at $425 \pm 170 \mathrm{~m}$ of depth if a shallow-seated, still hot, magmatic intrusion exists beneath the "Loma Blanca bulge".

According to data published by Arellano et al. (2003) and U2020, the H4 stratigraphic log does not show any evidence of intrusive bodies from the surface down to $1900 \mathrm{~m}$ of depth or a sharp increase in the temperature and geothermal gradient, which remains constant (about $20^{\circ} \mathrm{C} / 100 \mathrm{~m}$ ) (Fig. 4d). Also, the temperature profiles measured in several wells of the field (e.g. Arellano et al., 2003) do not show any strong temperature inversion or sharp change in the geothermal gradient possibly correlated to recent intrusive bodies at very shallow depths (“< $1 \mathrm{~km}$ ”) or any shallow-seated intrusive or sub-volcanic lithology (Cavazos-Álvarez et al., 2020). Lithological well logs show the presence of rhyoliticandesitic rock layers within the Caldera group (mainly in the Xaltipan ignimbrite unit; Carrasco-Núñez et al., 2017), which have been interpreted by U2020 as "intrusion of felsic cryptodomes within the volcanic sequence". A recent study of these felsic layers, based on petrographic and geochemical 


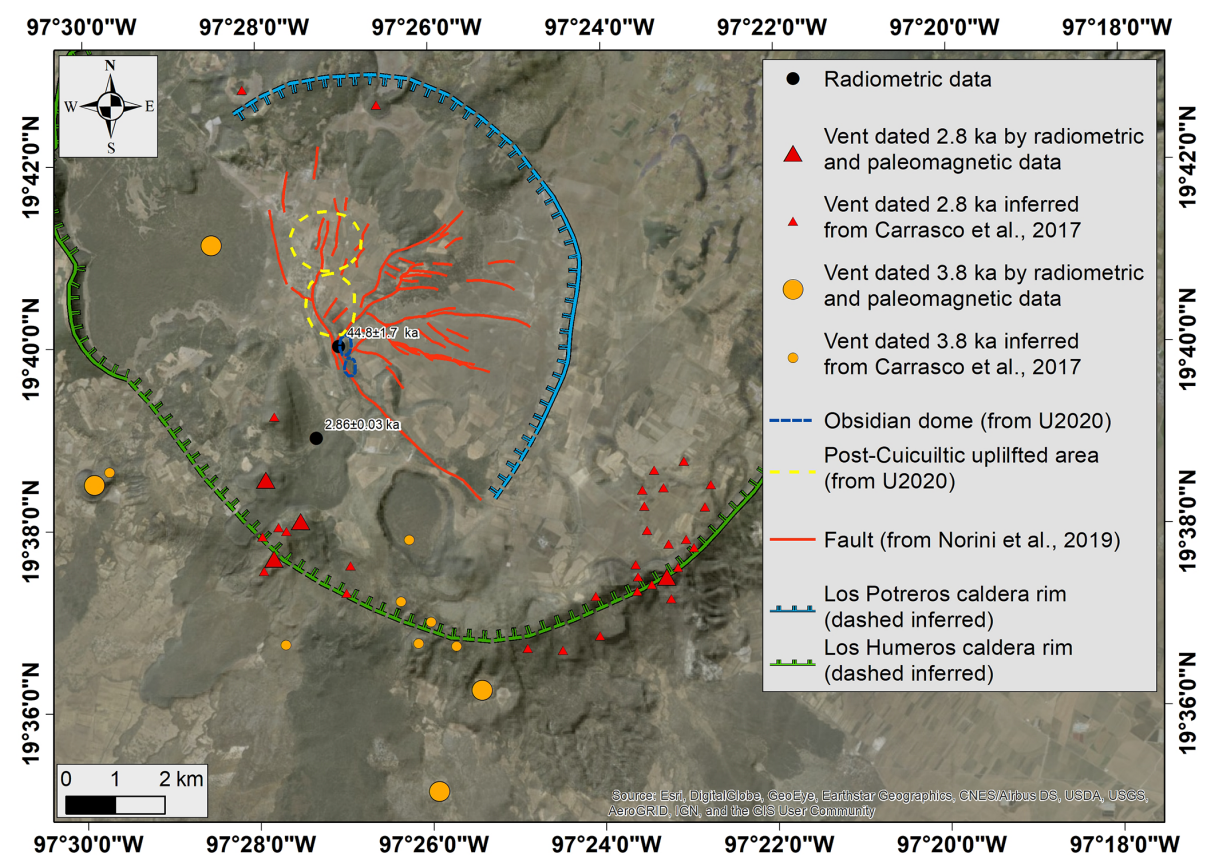

Figure 5. Map of the post-Cuicuiltic Member vents and ages based on radiometric data and palaeomagnetic analysis or inferred from geological maps (Carrasco-Núñez et al., 2017, 2018; Juárez-Arriaga et al., 2018). The post-Cuicuiltic Member uplifted areas and obsidian dome proposed by U2020 are also shown. Active faults are from Norini et al. (2019).

analyses of borehole samples, identified them as "lithic-rich breccias of local and irregular distribution that formed during the caldera collapse event" (Cavazos-Álvarez et al., 2020).

Published well log data indicate a deeper origin of the heat source (or sources) feeding the Los Humeros geothermal field, with some variation of the temperature gradient due to faults and/or permeability changes (Fig. 4d) (e.g. Cedillo et al., 1997; Arellano et al., 2003; Cavazos-Álvarez et al., 2020).

\section{Validation of the proposed model - stratigraphic and radiometric data}

One of the results presented in U2020 is that "the recent (post-caldera collapse) uplift in the Los Potreros caldera moved progressively northwards ... along the Los Humeros and Loma Blanca scarps". Based on the proposed U2020 uplift model, it suggests that shallow intrusions of small magmatic bodies and, consequently, the volcanic feeding system moved progressively northwards. This statement presents some discrepancies with the stratigraphy, geological mapping and radiometric ages published recently (CarrascoNúñez et al., 2017, 2018; Juárez-Arriaga et al., 2018), as summarized by the following points:

a. An obsidian dome (Qr1 rhyolite of Carrasco-Núñez et al., 2017) has been dated using the U-Th method at $44.8 \pm 1.7 \mathrm{ka}$ by Carrasco-Núñez et al. $(2017,2018)$. Its location corresponds to the obsidian dome cropping out along the Los Humeros fault described in U2020 and connected with the syn- to post-Cuicuiltic Member eruption (7.3-3.8 ka) (Fig. 5). In U2020 there is no description of two generations of obsidian domes along the Los Humeros fault, nor is there any explanation to invalidate the previous radiometric dating. Therefore, the U2020 attribution of this obsidian dome to the 7.33.8 ka volcanic-activity phase appears unjustified and, consequently, weakens their model.

b. The most recent volcanic activity of LHVC (postCuicuiltic Member) is clustered in two main ages, around 3.8 and $2.8 \mathrm{ka}$, as indicated by recent radiometric and palaeomagnetic data (Carrasco-Núñez et al., 2017; Juárez-Arriaga et al., 2018) (Fig. 5). According to these ages and the LHVC geological map (Carrasco-Núñez et al., 2017), the vents feeding the post-Cuicuiltic Member volcanic activity are mainly located close to the southern and south-western sectors of the Los Humeros caldera rim. These data suggest that the shallow feeding system of the post-Cuicuiltic Member activity is mainly located in the southern and south-western sectors of the LHVC, some kilometres away from the supposed bulged areas. Also, the ages and locations of the volcanic vents do not show any progressive northwards shift but a scattered activity along the Los Humeros caldera rim. 


\section{Conclusions}

We identified several problems in the U2020 study, showing that their model does not conform to most of the published geological data about the Los Potreros caldera. The boundary conditions of a model and the validation of the modelling results should always be based on the geological constraints that the natural prototype imposes. In our opinion, the multiple magmatic intrusion model is imposed by U2020 on the natural prototype regardless of several pieces of evidence of no fit between them. This mismatch between nature and model includes the age and location of faulting, identification and delimitation of uplifted areas and apical depressions, temperature and lithological well log, and stratigraphic and radiometric data. The occurrence of multiple magmatic intrusions at different depths in the Los Potreros caldera is not questioned in our comment. Published data indicate that the calculations and conclusions by U2020 are unlikely to have any relevance to the identification of the deformation source driving caldera resurgence and the heat source feeding the geothermal field. The data and interpretations discussed in our comment have scientific and economic implications. Indeed, they are important to planning the best strategies for geothermal exploration and production and reducing drilling risk and potential loss of investment.

Data availability. All the data presented in this paper are available upon request.

Supplement. The supplement related to this article is available online at: https://doi.org/10.5194/se-11-2549-2020-supplement.

Author contributions. GN and GG are equally responsible for conceptualization (research planning), investigation (field analysis, geomorphological analysis, review of well $\operatorname{logs}$ and stratigraphic data), writing of the original draft and review and editing, and visualization (figures and maps).

Competing interests. The authors declare that they have no conflict of interest.

Acknowledgements. The research leading to these results has received funding from the GEMex Project, funded by the European Union's Horizon 2020 research and innovation programme under grant agreement no. 727550 . We thank the handling topical editor Joachim Gottsmann for providing valuable comments on an earlier version of the manuscript. We also greatly thank Luca Ferrari and Joan Marti for their positive comments on our manuscript.
Financial support. This research has been supported by the European Union (grant no. GEMex (727550)).

Review statement. This paper was edited by Joachim Gottsmann and reviewed by Joan Marti.

\section{References}

Arellano, V. M., Garcia, A., Barragan, R. M., Izquierdo, G., Aragon, A., and Nieva, D.: An updated conceptual model of the Los Humeros geothermal reservoir (Mexico), J. Volcanol. Geotherm. Res., 124, 67-88, https://doi.org/10.1016/S03770273(03)00045-3, 2003.

Bonali, F., Corazzato, C., Bellotti, F., and Groppelli, G.: Active tectonics and its interactions with Copahue volcano, in: Copahue Volcano, edited by: Tassi, F., Vaselli, O., and Caselli, A. T., Springer, Berlin Heidelberg, 23-45, https://doi.org/10.1007/9783-662-48005-2_2, 2015.

Burbank, D. W. and Anderson, R. S.: Tectonic Geomorphology, Second Edition, John Wiley and Sons, Ltd, Chichester, UK, ISBN 978-1-444-34506-3, 274 pp., 2011.

Calcagno, P., Evanno, G., Trumpy, E., Gutiérrez-Negrín, L. C., Macías, J. L., Carrasco-Núñez, G., and Liotta, D.: Preliminary 3-D geological models of Los Humeros and Acoculco geothermal fields (Mexico) - H2020 GEMex Project, Adv. Geosci., 45, 321-333, https://doi.org/10.5194/adgeo-45-321-2018, 2018.

Carrasco-Núñez, G., Hernández, J., De León, L., Dávila, P., Norini, G., Bernal, J. P., Jicha, B., Navarro, M., López-Quiroz, P., and Digitalis, T.: Geologic Map of Los Humeros volcanic complex and geothermal field, eastern Trans-Mexican Volcanic Belt, Terra Digitalis, 1, 1-11, https://doi.org/10.22201/igg.terradigitalis.2017.2.24.78, 2017.

Carrasco-Núñez, G., Bernal, J. P., Davila, P., Jicha, B., Giordano, G., and Hernández, J.: Reappraisal of Los Humeros volcanic complex by new U/Th zircon and ${ }^{40} \mathrm{Ar} /{ }^{39} \mathrm{Ar}$ dating: Implications for greater geothermal potential, Geochem. Geophy. Geosy., 19, 132-149, https://doi.org/10.1002/2017GC007044, 2018.

Cavazos-Álvarez, J. A., Carrasco-Núñez, G., Dávila-Harris, P., Peña, D., Jáquez, A., and Arteaga, D.: Facies variations and permeability of ignimbrites in active geothermal systems; case study of the Xáltipan ignimbrite at Los Humeros Volcanic Complex, J. S. Am. Earth Sci., 104, 102810, https://doi.org/10.1016/j.jsames.2020.102810, 2020.

Cedillo, F.: Geologia del subsuelo del campo geotermico de Los Humeros, Pue. Internal Report HU/RE/03/97, Comision Federal de Electricidad, Gerencia de Proyectos Geotermoelectricos, Residencia Los Humeros, Puebla, 30 pp., 1997.

Dávila-Harris, P. and Carrasco-Núñez, G.: An unusual syn-eruptive bimodal eruption: The Holocene Cuicuiltic Member at Los Humeros caldera, Mexico, J. Volcanol. Geoth. Res., 271, 24-42, https://doi.org/10.1016/j.jvolgeores.2013.11.020, 2014.

Ferriz, H. and Mahood, G.: Eruptive rates and compositional trends at Los Humeros volcanic center, Puebla, Mexico, J. Geophys. Res., 89, 8511-8524, https://doi.org/10.1029/JB089iB10p08511, 1984. 
GEMex: Final report on active systems: Los Humeros and Acoculco, Deliverable 4.1. GEMex project technical report, Horizon 2020, European Union, available at: http://www. gemex-h2020.eu/index.php?lang=en (last access: 21 December 2020), 334 pp. 2019.

Giordano, G., Ahumada, F., Aldega, L., Baez, W., Becchio, R., Bigi, S., Caricchi, C., Chiodi, A., Corrado, S., De Benedetti, A., Favetto, A., Filipovich, R., Fusari, A., Groppelli, G., Invernizzi, C., Maffucci, R., Norini, G., Pinton, A., Pomposiello, C., Tassi, F., Taviani, S., and Viramonte, J.: Preliminary data on the structure and potential of the Tocomar geothermal field (Puna plateau, Argentina), Energy Procedia, 97, 202-209, https://doi.org/10.1016/j.egypro.2016.10.055, 2016.

Jackson, M. D. and Pollard D. D.: Flexure and faulting of sedimentary host rocks during growth of igneous domes, Henry Mountains, Utah, J. Struct. Geol., 12, 185-206, https://doi.org/10.1016/0191-8141(90)90004-I, 1990.

Juárez-Arriaga, E., Böhnel, H., Carrasco-Núñez, G., and Nasser Mahgoub, A.: Paleomagnetism of Holocene lava flows from Los Humeros caldera, eastern Mexico: Discrimination of volcanic eruptions and their age dating, J. S. Am. Earth Sci., 88, 736-748, https://doi.org/10.1016/j.jsames.2018.10.008, 2018.

Keller, E. A. and Pinter, N.: Active Tectonics: Earthquakes, Uplift, and Landscape, Second Edition, Prentice Hall, Upper Saddle River, ISBN 0130882305, 361 pp., 2002.
Norini, G., Groppelli, G., Sulpizio, R., Carrasco-Núñez, G., DávilaHarris, P., Pellicioli, C., Zucca, F., and De Franco, R.: Structural analysis and thermal remote sensing of the Los Humeros Volcanic Complex: Implications for volcano structure and geothermal exploration, J. Volcanol. Geoth. Res., 301, 221-237, https://doi.org/10.1016/j.jvolgeores.2015.05.014, 2015.

Norini, G., Carrasco-Núñez, G., Corbo-Camargo, F., Lermo, J., Hernández Rojas, J., Castro, C., Bonini, M., Montanari, D., Corti, G., Moratti, G., Chavez, G., Ramirez, M., and Cedillo, F.: The structural architecture of the Los Humeros volcanic complex and geothermal field, J. Volcanol. Geoth. Res., 381, 312-329, https://doi.org/10.1016/j.jvolgeores.2019.06.010, 2019.

Schofield, N., Stevenson, C., and Reston, T.: Magma fingers and host rock fluidization in the emplacement of sills, Geology, 38, 63-66, https://doi.org/10.1130/G30142.1, 2010.

Sibbett, B. S.: Size, depth and related structures of intrusions under stratovolcanoes and associated geothermal systems, Earth-Sci. Rev., 25, 291-309, https://doi.org/10.1016/00128252(88)90070-0, 1988.

Urbani, S., Giordano, G., Lucci, F., Rossetti, F., Acocella, V., and Carrasco-Núñez, G.: Estimating the depth and evolution of intrusions at resurgent calderas: Los Humeros (Mexico), Solid Earth, 11, 527-545, https://doi.org/10.5194/se-11-527-2020, 2020.

Wilson, P. I. R., McCaffrey, K. J. W., Wilson, R. W., Jarvis, I., and Holdsworth, R. E.: Deformation structures associated with the Trachyte Mesa intrusion, Henry Mountains, Utah: Implications for sill and laccolith emplacement mechanisms, J. Struct. Geol., 87, 30-46, https://doi.org/10.1016/j.jsg.2016.04.001, 2016. 